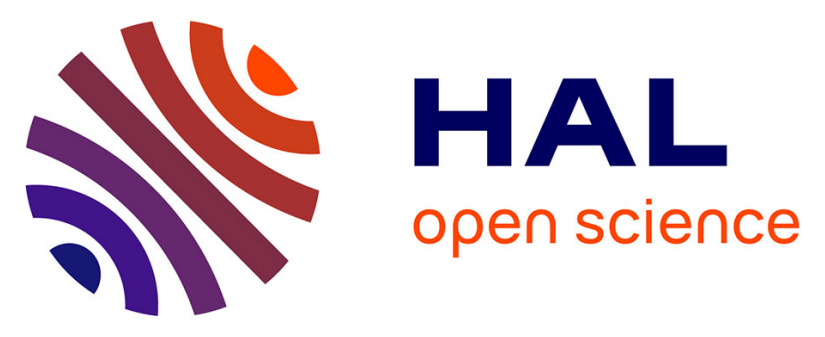

\title{
11q24.2q24.3 microdeletion in two families presenting features of Jacobsen syndrome, without intellectual disability Role of FLI1, ETS1, and SENCR long noncoding RNA
}

Solène Conrad, Florence Demurger, Kamran Moradkhani, Olivier Pichon, Cédric Le Caignec, Cécile Pascal, Caroline Thomas, Sophie Bayart, Antoinette Perlat, Christèle Dubourg, et al.

\section{- To cite this version:}

Solène Conrad, Florence Demurger, Kamran Moradkhani, Olivier Pichon, Cédric Le Caignec, et al.. 11q24.2q24.3 microdeletion in two families presenting features of Jacobsen syndrome, without intellectual disability Role of FLI1, ETS1, and SENCR long noncoding RNA. American Journal of Medical Genetics Part A, 2019, 179 (6), pp.993-1000. 10.1002/ajmg.a.61113 . hal-02091219

HAL Id: hal-02091219

https://hal-univ-rennes1.archives-ouvertes.fr/hal-02091219

Submitted on 18 Nov 2019

HAL is a multi-disciplinary open access archive for the deposit and dissemination of scientific research documents, whether they are published or not. The documents may come from teaching and research institutions in France or abroad, or from public or private research centers.
L'archive ouverte pluridisciplinaire HAL, est destinée au dépôt et à la diffusion de documents scientifiques de niveau recherche, publiés ou non, émanant des établissements d'enseignement et de recherche français ou étrangers, des laboratoires publics ou privés. 


\section{1q24.2q24.3 microdeletion in two families presenting features of Jacobsen syndrome, without intellectual disability: role of $F L I$, \\ ETS1 and SENCR long noncoding RNA}

Solène Conrad $^{1}$, Florence Demurger ${ }^{2}$, Kamran Moradkhani ${ }^{1}$, Olivier Pichon ${ }^{1}$, Cédric Le Caignec ${ }^{1,3}$,

Cécile Pascal ${ }^{4}$, Caroline Thomas ${ }^{5}$, Sophie Bayart ${ }^{6}$, Antoinette Perlat ${ }^{7}$, Christèle Dubourg ${ }^{8,9}$, Sylvie Jaillard $^{10,11}$, and Mathilde Nizon ${ }^{1,3}$

${ }^{1}$ Service de Génétique Médicale, CHU Nantes

${ }^{2}$ Service de Génétique Médicale, CHBA Vannes

${ }^{3}$ INSERM, CNRS, UNIV Nantes, I'Institut du Thorax, 44000 Nantes, France

${ }^{4}$ Service de Cardiologie pédiatrique et fœtale, Hôpital privé du Confluent, Nantes

${ }^{5}$ Service d'Hémato-oncologie pédiatrique, CHU Nantes

${ }^{6}$ Centre de traitement des maladies hémorragiques, $\mathrm{CHU}$ Rennes

${ }^{7}$ Service de Médecine Interne-Immunologie Clinique, CHU de Rennes

${ }^{8}$ Service de Génétique Moléculaire et Génomique, CHU Rennes, France 
${ }^{9}$ Univ Rennes, CNRS, IGDR (Institut de génétique et développement de Rennes) - UMR 6290, F 35000 Rennes, France

${ }^{10} \mathrm{CHU}$ Rennes, Service de Cytogénétique et Biologie Cellulaire, F-35033 Rennes, France

${ }^{11}$ INSERM U1085-IRSET, Université de Rennes 1, F-35042 Rennes, France 


\section{Corresponding author}

Mathilde Nizon, MD

Service de Génétique Médicale

Hôtel Dieu, CHU Nantes

1 place Alexis Ricordeau

44000 NANTES

0240083245

mathilde.nizon@chu-nantes.fr

\section{CONFLICT OF INTEREST STATEMEMENT}

The authors declare no competing interests.

KEYWORDS: Jacobsen syndrome, 11q24 deletion, FLI1, ETS1, SENCR, ARHGAP32, KIRREL3 


\section{ABSTRACT}

This report presents two families with interstitial 11q24.2q24.3 deletion, associated with malformations, hematologic features and typical facial dysmorphism, observed in Jacobsen syndrome, except for intellectual disability. The smallest $700 \mathrm{~Kb}$ deletion contains only two genes: FLI1 and ETS1, and a long noncoding RNA, SENCR, narrowing the minimal critical region for some features of Jacobsen syndrome. Consistent with recent literature, it adds supplemental data to confirm the crucial role of FLI1 and ETS1 in Jacobsen syndrome: namely FLI1 in thrombocytopenia and ETS1 in cardiopathy and immune deficiency. It also supports that combined ETS1 and FLI1 haploinsufficiency explains dysmorphic features, notably ears and nose anomalies. Moreover, it raises the possibility that SENCR, a long noncoding RNA, could be responsible for limb defects, because of its early role in endothelial cell commitment and function. Considering intellectual disability and autism spectrum disorder, which are some of the main features of Jacobsen syndrome, a participation of ETS1, FLI1 or SENCR cannot be excluded. But, considering the normal neurodevelopment of our patients, their role would be either minor or with an important variability in penetrance. Furthermore, according to literature, ARHGAP32 and KIRREL3 seem to be the strongest candidate genes in the 11q24 region for other Jacobsen patients.

\section{INTRODUCTION}

Jacobsen syndrome (JS) [OMIM\#147791] is considered as a contiguous gene disorder caused by a large terminal or interstitial deletion of the long arm of chromosome 11. It was first described in 1973 by the Danish genetist Petrea Jacobsen [Jacobsen et al., 1973]. JS is characterized by intellectual disability (ID) of variable severity, typical facial dysmorphism, thrombocytopenia, pre- 
and postnatal growth restriction, immune deficiency, autism spectrum disorders (ASD) and a wide range of malformations, mainly heart malformation (50\%). Yet, over 200 cases have been described [Favier et al., 2015; Mattina et al., 2009; Grossfeld et al., 2004; Fryns et al., 1986]. Through genotypephenotype correlations and animal models, several genes have been proposed to contribute to JS phenotype, especially FLI1 and ETS1 [Favier et al., 2015; Carpinelli et al., 2015; Ye et al., 2010; Hart et al., 2000].

Here, we report on five new patients from two families that harbor very small inherited interstitial deletions within the region 11q24.2-q24.3 deleted in Jacobsen syndrome. All have the main features of Jacobsen syndrome, namely dysmorphism, malformations, thrombocytopenia and immune deficiency but normal cognitive development. Our study provides new insights about the role of FLI1 and ETS1 and confirms the crucial role of these two genes for JS phenotypes. It also raises the possibility that SENCR, a long noncoding RNA, could be responsible for limb defects, because of its early role in endothelial cell commitment and function. Then, it supports the role of causal genes for ID and/or ASD outside of the smallest deletion.

\section{MATERIALS AND METHODS}

\section{Clinical assessment}

Both children have been referred to genetic consultations by pediatricians considering the multiple malformations, notably limb defects. Family B was included in this study thanks to a national cooperative effort collecting rare CNV in syndromic disorders.

Family A 
Patient III-2 (Fig1-1) was the first female child of unrelated French parents. Increased nuchal translucency was noticed at $1^{\text {st }}$ trimester, with a normal karyotype. She was born at 37 WG, with normal measurements. At birth, severe brachydactyly of the left foot (Fig 1-2, C), mainly on the $3^{\text {rd }}$ and $4^{\text {th }}$ toes was noted, associated with a subaortic ventricular septal defect (VSD), initially large, which closed spontaneously within the $1^{\text {st }}$ year of life, requiring no surgical treatment, a mild umbilical hernia and a small sacro-coccygeal fossea. Abdominal ultrasound was unremarkable. She presented dysmorphism with high forehead, hypertelorism, unilateral ptosis, epicanthal folds, broad nasal bridge with bulbous tip, dysplastic and little ears (Fig 1-2, C). Blood count showed fluctuating thrombocytopenia (minimum 137G/I) with elevated size of the platelets (12fl), transitory lymphopenia (1.43 G/l) encompassing all lymphocyte sub-populations, normal quantitative immunoglobulins and inconsistent microcytic anemia (9.6 g/dl, VGM $74.9 \mathrm{fl})$. She walked at 18 months, with normal development of other motor skills and no language delay at the age of 22 months.

Her mother (II-3) presented similar dysmorphism with downslanting palpebral fissures, mild hypertelorism, short nose and small, low-set, posteriorly rotated ears (Fig 1-2, B). She underwent surgeries in infancy for strabismus and unilateral ptosis. She had spontaneous closure of a ventricular septal defect in infancy. She presented mild thrombocytopenia occurring during pregnancy without hemorrhagic event. Cognitive development was normal. She worked as a caregiver.

Her maternal grandfather (I-3) also presented mild dysmorphism with short nose, protruding and posteriorly rotated ears, flat philtrum, thin upper lip, short neck (Fig 1-2, A). He has suffered from chronic bronchitis since the age of 20 . He presented asymptomatic thrombocytopenia and 
moderate lymphopenia $(1,13 \mathrm{G} / \mathrm{I})$. Quantitative immunoglobulins were normal. He had no learning difficulties. He worked as a team leader in an electrical grid company.

\section{Family B}

Patient III-2 was the first male child of unrelated French parents (fig 1-1). Pregnancy was marked by intrauterine growth restriction and increased nuchal translucency at $3.4 \mathrm{~mm}$. Prenatal karyotype was normal. On $2^{\text {nd }}$ trimester, left hand anomaly was detected. He was born hypotrophic at 37 WG: birth weight 2415g (-1.5 SD), length $45 \mathrm{~cm}$ (-1.5 SD). Apgar score was 5/9, with a transitory respiratory distress. At birth he presented mild axial hypotonia and peripheric hypertonia, hypospadias, mild pectum carinatum and facial dysmorphism with discrete plagiocephaly, prominent forehead, dysplastic and low-set ears, relatively long philtrum, anteverted nostrils and short neck. He presented severe brachydactyly on the left hand with $2^{\text {nd }}, 3^{\text {rd }}, 4^{\text {th }}$ and $5^{\text {th }}$ fingers present as nubbins and clinodactyly of the right $5^{\text {th }}$ finger. Abdominal ultrasound found a small, unilateral and transient pyelectasis. On blood count, fluctuant thrombocytopenia (minimum at $46 \mathrm{G} / \mathrm{I}$ ), anisocytosis and giant platelets, lymphopenia, immunoglobulin G deficiency and transitory anemia $(9.7 \mathrm{~g} / \mathrm{dl})$ were reported. No cardiac malformation was noticed. At 9 months, growth parameters and psychomotor development were normal.

His mother (II-2) presented mild dysmorphism with high forehead, downslanting palpebral fissures, short nose, long philtrum with thin upper lip and short neck. She had surgery in infancy for protruding ears. She presented persistent thrombocytopenia (60G/I), lymphopenia $(0.75 \mathrm{G} / \mathrm{I})$ and global hypogammaglobulinemia (IgG $2.4 \mathrm{~g} / \mathrm{l}, \operatorname{lgA} 0.5 \mathrm{~g} / \mathrm{l}, \operatorname{lgM} 0.34 \mathrm{~g} / \mathrm{l})$. She experienced pulmonary embolism 1 month after delivery. Cognitive development was normal. She went to graduate school. 


\section{DNA analysis}

Written informed parent consents were obtained for genetics analysis. DNA was extracted from peripheral blood lymphocytes.

Array CGH (Comparative genomic hybridization) was performed using the oligonucleotide $60 \mathrm{~K}$ microarray platform (Agilent) for family $\mathrm{A}$ and the oligonucleotide $4 \times 180 \mathrm{~K}$ microarray platform (Agilent) for family B. Patient and pooled same-sex reference DNA were labeled with Cy5-dCTP and Cy3-dCTP respectively and hybridized to the array platform, as recommended by the manufacturer's protocol (Agilent Technologies). Data analysis was performed using Cytogenomics 3.0.2.11.

FISH (Fluorescence in situ hybridization) analysis was performed on metaphases using probe RP11-754N12 (11q24.3) and control probe CTC-908H22 for family A and using probe RP11138K22 (11q24.3) and control probe RP11-243M7 (11q15.4) for family B. Data analysis was performed using CytoVysion 7.3.

\section{Ethics statement}

The study was approved by an ethics committee.

\section{RESULTS}

Array CGH analysis in family A proband (III-2) identified a 700kb interstitial 11q24.3 deletion (arr[GRCh37]11q24.3(127970179_128673011)x1) containing two OMIM genes: ETS1 (OMIM 164720) (V-Ets Avian Erythroblastosis Virus E26 Oncogene Homolog 1) and FLI (OMIM 193067) (Friend Leukemia Virus Integration 1), and a cytoplasmatic long noncoding RNA, SENCR (OMIM 615815) 
(smooth muscle and endothelial cell-enriched migration/differentiation-associated long noncoding RNA) (Supplemental data). FISH analysis confirmed the deletion in the proband and showed that it was inherited from the mother and the maternal grand-father (Supplemental data).

Array CGH in family B proband (III-2) showed a $1.5 \mathrm{Mb}$ interstitial 11q24.2q24.3 deletion (arr[GRCh37]11q24.2q24.3(127679132_129196108)x1) including the three genes above and five other ones: KCNJ1 (OMIM 600359), KCNJ5 (OMIM 600734), TP53AIP1 (OMIM 605426), C11orf45 and ARHGAP32 (OMIM 608541) (Supplemental data). The deletion was confirmed by FISH analysis, showing that it was inherited from the mother (Supplemental data).

\section{DISCUSSION}

Here we report two families with inherited interstitial deletions in 11q24.2q24.3 region, which are the smallest ever described in Jacobsen locus (respectively 700kb and $1.5 \mathrm{Mb}$, Fig 2, Table 1). Family A deletion encompasses only two genes: FLI1, ETS1 and a long noncoding RNA, SENCR, supporting the recent advances concerning the crucial role of FLI1 and ETS1 in some Jacobsen syndrome features.

FLI1 is involved in Paris-Trousseau syndrome (PTS), a highly penetrant platelet disorder in JS (88\%) [Favier et al., 2003; Grossfeld et al., 2004]. PTS is characterized by a neonatal thrombocytopenia which may resolve over time and a platelet dysfunction usually persistent throughout life. Platelets often contain giant alpha granules. FLI1 transcription factor interacts with genes involved in vasculogenesis, hematopoiesis and intercellular adhesion. Flit/- mice expressed thrombocytopenia and Fli-/- mice had an embryonic lethality due to cranial hemorrhages [Hart et al., 
2000]. In humans, a few heterozygous FLII missense and frameshift variants in the DNA-binding domain have been shown to cause platelet disorder [Stevenson et al., 2015; Stockley et al., 2013]. In our series, all patients present FLI1 haploinsufficiency and express a variable thrombocytopenia which supports the role of $F L I 1$ in platelet dysfunction.

ETS1 is highly suspected to cause congenital heart malformations, a major cause of morbidity in JS with a penetrance over $50 \%$, mostly ventricular septal defects and hypoplastic left heart syndrome [Grossfeld et al., 2004]. ETS1 transcription factor is expressed in vascular endothelium, endocardium and neural crests. It is necessary for heart cell migration and differentiation [Beh et al., 2007]. Ets1-/- xenopus showed hypoplastic left heart syndrome-like [Nie and Bronner, 2015] and Ets1-/- mice showed membranous ventricular septal defects, bifid cardiac apex, and non-apex-forming left ventricle which are frequent cardiac malformations in JS [Ye et al., 2010]. By whole-exome sequencing, a de novo ETS1 frameshift variant in a patient with heart malformation was identified [Glessner et al., 2014]. In our series, all patients showed ETS1 haploinsufficiency, but only two had a septal defect, which is consistent with an incomplete penetrance.

Congenital anomalies of the kidney and urinary tract (CAKUT) are quite frequent in JS, occurring in $13 \%$ of the patients [Grossfeld et al., 2004]. These are mostly duplicated ureters, unilateral renal agenesis, dysplastic kidneys, narrowed ureters and dilated renal calyces. Recently, Ye et al., (2018) highlighted the role of ETS1 in structural kidney defects, by defining an 8.1 Mb "kidney critical region" through genotype-phenotype correlations. Furthermore, they demonstrated that deletion of Ets-1 in mice causes kidneys defects (duplicated kidneys, hypoplastic kidneys, dilated renal pelvis and calyces) [Ye et al., 2018]. Interestingly, in our study patient B-III-2 presented a mild 
resolutive pyelectasia, which could be related to ETS1. Renal ultrasound was normal in patient A-III-2 and data is not available for other patients.

ETS1 is also involved in immune deficiency and autoimmunity. Low IgG levels, decreased number of memory $\mathrm{B}, \mathrm{T}$ or NK cells and impaired response to $S$. pneumoniae polysaccharide vaccination were described in JS patients [Dalm et al., 2015]. ETS1 is highly expressed in lymphoid tissues and cells. Knockout Ets1 mice showed aberrations in B cells differentiation, aberrant thymic differentiation, reduced peripheral levels of T and NK cells and impaired IL-2, Th1 and Th2 production [Blazina et al., 2016]. In our series, all patients presented an immune deficiency (lymphopenia and/or hypogammaglobulinemia), supporting the role of ETS1.

Combined FLI1 and ETS1 haploinsufficiency was suspected to cause craniofacial and middle ear abnormalities, on mice model [Carpinelli et al., 2015]. ETS1 and FLI1 both belong to the ETS transcription factor family and are highly conserved during evolution. They probably result from the duplication of the same gene and possibly have redundant functions. Fli1+/- mice had short nasal bone, hearing loss, otitis media (inflammatory epithelia) and mild thrombocytopenia [Carpinelli et al., 2015]. Ets1+/-Fli1+/- mice expressed the same features but with a more severe phenotype, and specific ear malformations (small middle ear cavity, deformation of the stapes, ossicle fixation). Abnormal migration, proliferation or differentiation of neural crest cells in the frontonasal process, depending on both ETS1 and FLI1, is suspected. Unlike JS patients, who have frequent hypertelorism, the inner canthal distances were normal in $\mathrm{Fli1}^{+/-}$and $\mathrm{Ets}^{+/-} \mathrm{Fli1}^{+/-}$mice. Similar dysmorphism in our series' patients supports the role of combined FLI1 and ETS1 haploinsufficiency in humans for this feature, especially for nose and ear morphology. 
Transversal limb defects are rarely considered secondary to genetic factors but concern two patients is our series. Limb malformations described in JS are mostly finger syndactyly, finger pads or $\mathrm{V}^{\text {th }}$ finger clinodactyly [Grossfeld et al., 2004]. Nevertheless, transverse limb defects have already been reported three times in JS [Von Bubnoff et al., 2004; So et al., 2014; Fujita et al., 2010]. Low penetrance of this malformation could be explained by a multifactorial model. Thrombocytopenia, due to FLI1 deletion, could be responsible for prenatal hemorrhage and consequently interrupt limb vascularization, as suggested in Poland syndrome. ETS factors act directly on the ZRS (ZPA regulatory sequence) mediating a differential effect on Sonic hedgehog (SHH). However, variants in ETS factors lead to preaxial polydactyly [Lettice et al., 2012]. SENCR, a long noncoding RNA regulating the endothelial and smooth muscle cell differentiation, overlaps with FLI1 in $1^{\text {st }}$ intron in the antisense direction, but knockdown of SENCR has no effect on FLI1 and neighboring genes. However, it regulates the expression of HCASMCs (human artery, heart, lung, skin, and skeletal muscle) genes [Boulberdaa et al., 2016]. On HUVEC (human umbilical endothelial cells), SENCR was shown as an early induced IncRNA promoting mesodermal and endothelial cell (EC) commitment [Boulberdaa et al., 2016]. The EC migratory capacity was respectively inhibited or stimulated after SENCR silencing or overexpression. SENCR expression was down regulated in critical limb ischemia tissues and in endothelial cells derived from premature coronary artery disease [Boulberdaa et al., 2016], suggesting a role of SENCR in limb ischemia.

Intellectual disability (ID) is a main feature in Jacobsen syndrome (85 \% [Grossfeld et al., 2004]). Likewise, autism spectrum disorders (ASD) have been recently shown in a subsequent part of JS patients (47\% [Akshoomoff et al., 2015]). However, strikingly, our patients had normal psychomotor and cognitive development, even if mild neurodevelopmental disorders (NDD) could develop in both children as they grow up. Given the varying penetrance of NDD in JS, it cannot be 
concluded that ETS1, FLI1 and SENCR do not participate, even if it seems very unlikely. To note, one patient was identified with an ETS1 de novo variant in association with congenital heart disease and intellectual disability (encephalopathic epilepsy), by WES [Homsy et al. 2015]. However no data concerning other variants identified by exome were available. It could be interesting to check if other variants could explain the encephalopathic epilepsy.

According to the recent literature ARHGAP32 and KIRREL3 seem to be the strongest candidate genes for ID and/or ASD in 11q24.2q24.3 region. ARHGAP32 encodes a neuron-associated GTPase-activating protein that regulates dendritic spine morphology and strength [Akshoomoff et al., 2015]. ARHGAP32 is expressed early in brain mouse development. ARHGAP32-deficient neurons showed reduced $\gamma$-aminobutyric acid type $A$ receptor $\left(G A B A_{A} R\right)$ levels and impaired $G A B A_{A} R$ mediated synaptic transmission. ARHGAP32-deficient mice exhibited ASD-like social behavior [Nakamura et al., 2016]. Several patients have been reported with larger 11q24 deletion encompassing ARHGAP32, all presenting with ID or autistic features [Akshoomoff et al., 2015]. To note, one patient expressed nonsyndromic ID and ASD with a 240 kb deletion containing only KCJN1, KCJN5, TP53AIP, and ARHGAP32, supporting the causal role of ARHGAP32 in NDD. However, patients from family B have normal neurodevelopment so far, but this data could be consistent with an incomplete penetrance of ARHGAP32 in ASD and ID.

KIRREL3 (OMIM 607761) codes for a synaptic molecule of the immunoglobulin superfamily. Three missense variants in KIRREL3 have been identified in five patients with mild to severe ID [Bhalla et al., 2008]. Furthermore, Kirre/3-/- mice have been shown to express hyperactivity, autistic features [Hisaoka et al., 2018] and recognition memory deficit [Choi et al., 2015]. Guerin et al., (2012) described a single patient with a $2.89-\mathrm{Mb}$ deletion in distal $11 \mathrm{q}$ who had autistic features and 
neurodevelopmental delay and proposed KIRREL3 as a candidate for causing neurologic features in the patient. Interestingly, the deletion also contains ARHGAP32 so it is not possible to conclude on the causal role of only one gene. Moreover, Akshoomoff et al., (2015) found ASD in patients without deletion of KIRREL3 suggesting that this gene is not causal for all patients with distal 11q deletions.

In conclusion, we have presented the two smallest 11q24.2q24.3 inherited deletions in two families having the main features of Jacobsen syndrome but with no cognitive impairment. This study, in addition to data resulting from the literature, underpins the role of FLI1 in Paris-Trousseau syndrome, ETS1 in cardiopathy and immune deficiency, and combined ETS1 and FLI1 haploinsufficiency in facial dysmorphism. The long non coding RNA, SENCR, could be involved in transversal limb defect. Finally, the report can suggest the role of other genes outside the smallest deletion in intellectual disability, namely KIRREL3 and ARHGAP32. However, this complex region will need further explorations in order to be well defined. 


\section{Bibliography}

Akshoomoff N, Mattson SN, Grossfeld PD. 2015. Evidence for autism spectrum disorder in Jacobsen syndrome: identification of a candidate gene in distal 11q. Genet. Med. 17: 143-148.

Beh J, Shi W, Levine M, Davidson B, Christiaen L. 2007. FoxF is essential for FGF-induced migration of heart progenitor cells in the ascidian Ciona intestinalis. Dev. Camb. Engl. 134: 3297-3305.

Bhalla K, Luo Y, Buchan T, Beachem MA, Guzauskas GF, Ladd S, Bratcher SJ, Schroer RJ, Balsamo J, DuPont BR, Lilien J, Srivastava AK. 2008. Alterations in CDH15 and KIRREL3 in Patients with Mild to Severe Intellectual Disability. Am. J. Hum. Genet. 83: 703-713.

Blazina Š, Ihan A, Lovrečić L, Hovnik T. 2016. 11q terminal deletion and combined immunodeficiency (Jacobsen syndrome): Case report and literature review on immunodeficiency in Jacobsen syndrome. Am. J. Med. Genet. A. 170: 3237-3240.

Boulberdaa M, Scott E, Ballantyne M, Garcia R, Descamps B, Angelini GD, Brittan M, Hunter A, McBride M, McClure J, Miano JM, Emanueli C, Mills NL, Mountford JC, Baker AH. 2016. A Role for the Long Noncoding RNA SENCR in Commitment and Function of Endothelial Cells. Mol. Ther. J. Am. Soc. Gene Ther. 24: 978-990.

Von Bubnoff D, Kreiß-Nachtsheim M, Novak N, Engels E, Engels H, Behrend C, Propping P, de la Salle $\mathrm{H}$, Bieber T. 2004. Primary immunodeficiency in combination with transverse upper limb defect and anal atresia in a 34-year-old patient with Jacobsen syndrome. Am. J. Med. Genet. A. 126A: 293-298.

Carpinelli MR, Kruse EA, Arhatari BD, Debrincat MA, Ogier JM, Bories J-C, Kile BT, Burt RA. 2015. Mice Haploinsufficient for Ets1 and Fli1 Display Middle Ear Abnormalities and Model Aspects of Jacobsen Syndrome. Am. J. Pathol. 185: 1867-1876.

Choi S-Y, Han K, Cutforth T, Chung W, Park H, Lee D, Kim R, Kim M-H, Choi Y, Shen K, Kim E. 2015. Mice lacking the synaptic adhesion molecule Neph2/Kirrel3 display moderate hyperactivity and defective novel object preference. Front. Cell. Neurosci. 9: 283.

Dalm VASH, Driessen GJA, Barendregt BH, van Hagen PM, van der Burg M. 2015. The 11q Terminal Deletion Disorder Jacobsen Syndrome is a Syndromic Primary Immunodeficiency. J. Clin. Immunol. 35: 761-768.

Favier R, Akshoomoff N, Mattson S, Grossfeld P. 2015. Jacobsen syndrome: Advances in our knowledge of phenotype and genotype: AMERICAN JOURNAL OF MEDICAL GENETICS PART C (SEMINARS IN MEDICAL GENETICS). Am. J. Med. Genet. C Semin. Med. Genet. 169: 239-250.

Favier R, Jondeau K, Boutard P, Grossfeld P, Reinert P, Jones C, Bertoni F, Cramer EM. 2003. ParisTrousseau syndrome : clinical, hematological, molecular data of ten new cases. Thromb. Haemost. 
Fryns JP, Kleczkowska A, Buttiens M, Marien P, Berghe H den. 1986. Distal 11q monosomy. The typical 11q monosomy syndrome is due to deletion of subband 11q24. 1. Clin. Genet. 30: 255-260.

Fujita H, Yanagi T, Kosaki R, Torii C, Bamba M, Takahashi T, Kosaki K. 2010. Transverse limb defect in a patient with Jacobsen syndrome: Concurrence of malformation and disruption. Am. J. Med. Genet. A. 152A: 1033-1035.

Glessner JT, Bick AG, Ito K, Homsy J, Rodriguez-Murillo L, Fromer M, Mazaika E, Vardarajan B, Italia M, Leipzig J, DePalma SR, Golhar R, Sanders SJ, Yamrom B, Ronemus M, lossifov I, Willsey AJ, State MW, Kaltman JR, White PS, Shen Y, Warburton D, Brueckner M, Seidman C, Goldmuntz E, Gelb BD, Lifton R, Seidman J, Hakonarson H, Chung WK. 2014. Increased Frequency of De Novo Copy Number Variations in Congenital Heart Disease by Integrative Analysis of SNP Array and Exome Sequence Data. Circ. Res. 115: 884-896.

Grossfeld PD, Mattina T, Lai Z, Favier R, Jones KL, Cotter F, Jones C, the 11q Consortium. 2004. The $11 q$ terminal deletion disorder: A prospective study of 110 cases. Am. J. Med. Genet. 129A: 51-61.

Guerin A, Stavropoulos DJ, Diab Y, Chénier S, Christensen H, Kahr WH, Babul-Hirji R, Chitayat D. 2012. Interstitial deletion of $11 q$-implicating the KIRREL3 gene in the neurocognitive delay associated with Jacobsen syndrome. Am. J. Med. Genet. A. 158A: 2551-2556.

Hart A, Melet F, Grossfeld P, Chien K, Jones C, Tunnacliffe A, Favier R, Bernstein A. 2000. Fli-1 is required for murine vascular and megakaryocytic development and is hemizygously deleted in patients with thrombocytopenia. Immunity 13: 167-177.

Hisaoka T, Komori T, Kitamura T, Morikawa Y. 2018. Abnormal behaviours relevant to neurodevelopmental disorders in Kirrel3-knockout mice. Sci. Rep. 8: 1408.

International Collaborative Study Group for Bartter-like Syndromes. 1997. Mutations in the gene encoding the inwardly-rectifying renal potassium channel, ROMK, cause the antenatal variant of Bartter syndrome: evidence for genetic heterogeneity. Hum. Mol. Genet. 6: 17-26.

Jacobsen P, Hauge M, Henningsen K, Hobolth N, Mikkelsen M, Philip J. 1973. An (11;21) Translocation in Four Generations with Chromosome 11 Abnormalities in the Offspring. Hum. Hered. 23: 568-585.

Lettice LA, Williamson I, Wiltshire JH, Peluso S, Devenney PS, Hill AE, Essafi A, Hagman J, Mort R, Grimes G, DeAngelis CL, Hill RE. 2012. Opposing Functions of the ETS Factor Family Define Shh Spatial Expression in Limb Buds and Underlie Polydactyly. Dev. Cell 22: 459-467.

Mattina T, Perrotta CS, Grossfeld P. 2009. Jacobsen syndrome. Orphanet J. Rare Dis. 4: 9.

Nie S, Bronner ME. 2015. Dual developmental role of transcriptional regulator Ets1 in Xenopus cardiac neural crest vs. heart mesoderm. Cardiovasc. Res. 106: 67-75. 
So J, Stockley T, Stavropoulos DJ. 2014. Periventricular nodular heterotopia and transverse limb reduction defect in a woman with interstitial 11q24 deletion in the Jacobsen syndrome region. Am. J. Med. Genet. A. 164: 511-515.

Stevenson WS, Rabbolini DJ, Beutler L, Chen Q, Gabrielli S, Mackay JP, Brighton TA, Ward CM, MorelKopp M-C. 2015. Paris-Trousseau thrombocytopenia is phenocopied by the autosomal recessive inheritance of a DNA-binding domain mutation in FLI1. Blood 126: 2027-2030.

Stockley J, Morgan NV, Bem D, Lowe GC, Lordkipanidzé M, Dawood B, Simpson MA, Macfarlane K, Horner K, Leo VC, Talks K, Motwani J, Wilde JT, Collins PW, Makris M, Watson SP, Daly ME, UK Genotyping and Phenotyping of Platelets Study Group. 2013. Enrichment of FLI1 and RUNX1 mutations in families with excessive bleeding and platelet dense granule secretion defects. Blood 122: 4090-4093.

Tassano E, Janis S, Canepa A, Zanotto E, Torello C, Gimelli G, Cuoco C. 2016. Interstitial 11q24 deletion: a new case and review of the literature. J. Appl. Genet. 57: 357-362.

Ye M, Coldren C, Liang X, Mattina T, Goldmuntz E, Benson DW, Ivy D, Perryman MB, Garrett-Sinha LA, Grossfeld P. 2010. Deletion of ETS-1, a gene in the Jacobsen syndrome critical region, causes ventricular septal defects and abnormal ventricular morphology in mice. Hum. Mol. Genet. 19: 648-656.

Ye M, Xu L, Fu M, Chen D, Mattina T, Zufardi O, Rossi E, Bush KT, Nigam SK, Grossfeld P. 2018. Genetargeted deletion in mice of the Ets -1 transcription factor, a candidate gene in the Jacobsen syndrome kidney "critical region," causes abnormal kidney development: Gene-targeted deletion in mice of the Ets-1 transcription factor, a candidate gene in the Jacobsen syndrome kidney "critical region," causes abnormal. Am. J. Med. Genet. A. 


\section{FIGURES LEGEND}

Figure 1

Fig 1-1) Pedigrees of Family A and B

Fig 1-2) Pictures of Family A members.
A) Patient I-3, grandfather, 65 years-old
B) Patient II-3, mother, 33 years-old
C) Patient III-2, proband, aged 9 months. See the left foot showing severe brachydactyly.

Figure 2: Overview of the 11q24.2q24.3 region. Deletion size comparison between our cases and previously reported interstitial or short terminal deletions encompassing 11q24.2q24.3 region. 


\section{FIGURES}

\section{FIGURE 1}

Figure 1-1)

Family A

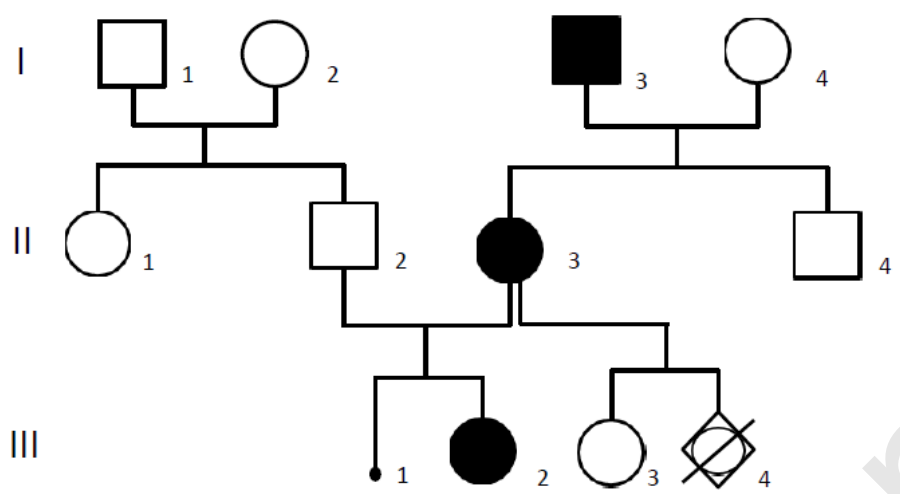

Family B

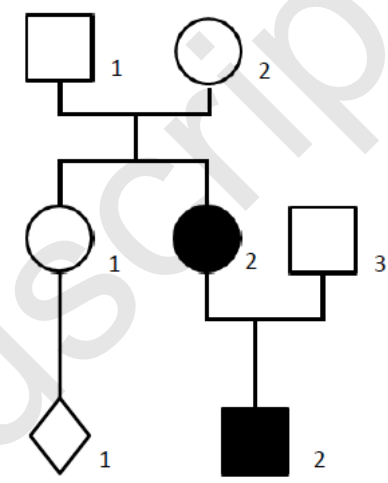

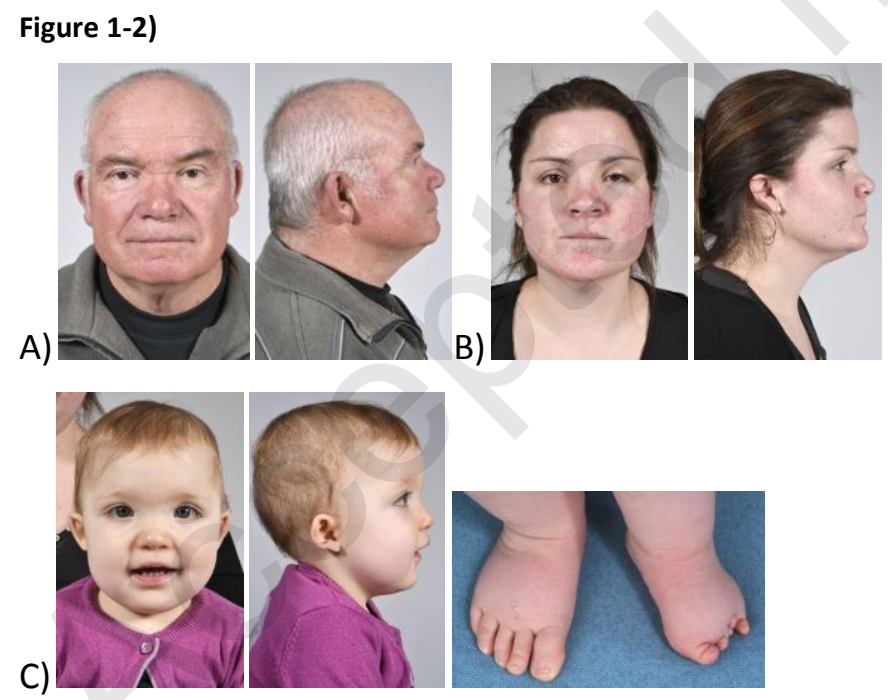


Figure 2

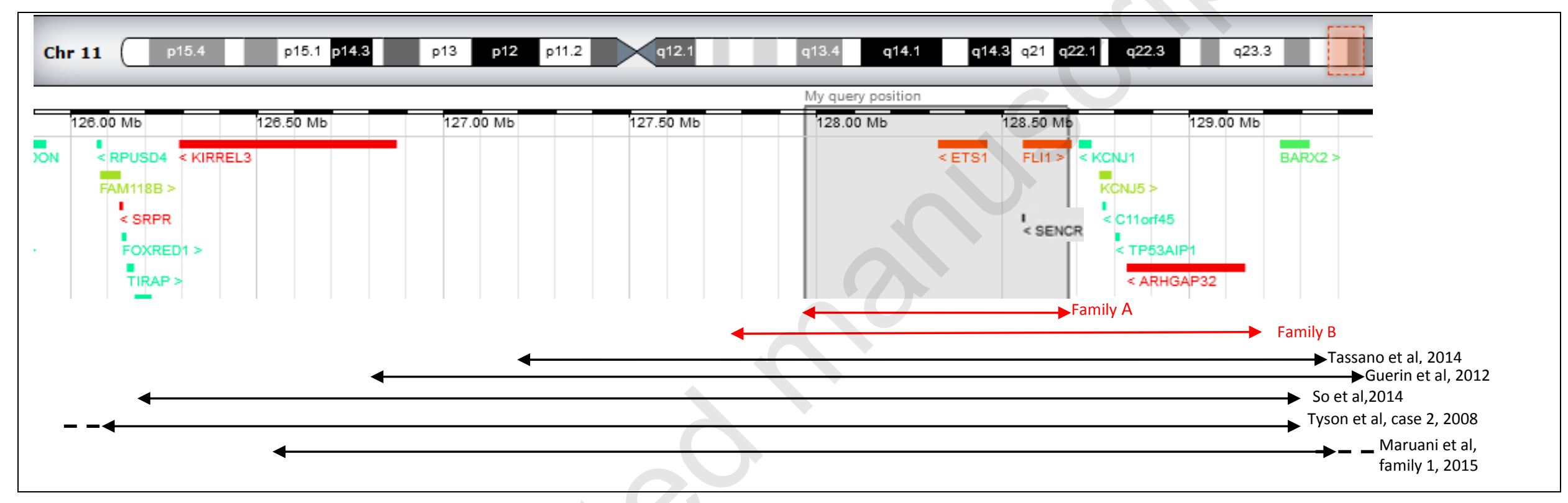


TABLE 1

\begin{tabular}{|c|c|c|c|c|c|c|c|c|c|c|c|c|}
\hline & & \multicolumn{3}{|c|}{ Family A } & \multicolumn{2}{|c|}{ Family B } & \multirow{2}{*}{$\begin{array}{l}\text { Tassano et } \\
\text { al.2014 }\end{array}$} & \multirow{2}{*}{$\begin{array}{l}\text { Guerin et al. } \\
2012\end{array}$} & \multirow[t]{2}{*}{ So et al. 2014} & \multirow{2}{*}{$\begin{array}{l}\text { Tyson et al. } \\
2008 \text { case } 2\end{array}$} & \multirow{2}{*}{$\begin{array}{l}\text { Maruani et } \\
\text { al. } \quad 2015 \\
\text { family } 1\end{array}$} & \multirow{2}{*}{$\begin{array}{l}\text { Features } \\
\text { frequency in JS } \\
\text { (\%) (Grossfeld } \\
\text { et al. 2004) }\end{array}$} \\
\hline & & Patient III-2 & Patient II-3 & Patient I-3 & Patient III-2 & Patient II-2 & & & & & & \\
\hline \multicolumn{2}{|c|}{$\begin{array}{l}\text { Size of the deletion and localization } \\
\text { (Hg19) }\end{array}$} & \multicolumn{3}{|c|}{$\begin{array}{c}700 \mathrm{~kb} \\
11 \mathrm{q} 24.3 \\
(127970179-128673011)\end{array}$} & \multicolumn{2}{|c|}{$\begin{array}{c}1.5 \mathrm{Mb} \\
11 \mathrm{q} 24.2 \mathrm{q} 24.3 \\
(127679132-129196108)\end{array}$} & $\begin{array}{l}2.4 \mathrm{Mb} \\
11 \mathrm{q} 24.2 \mathrm{q} 24.3 \\
(127217775- \\
129666990)\end{array}$ & $\begin{array}{l}2.9 \quad \mathrm{Mb} \\
11 \mathrm{q} 24.2 \mathrm{q} 24.3 \\
(127262460- \\
130161921)\end{array}$ & $\begin{array}{l}3.16 \mathrm{Mb} \\
11 \mathrm{q} 24.2 \mathrm{q} 24.3 \\
(125780310- \\
128942331)\end{array}$ & $\begin{array}{l}4.74 \mathrm{Mb} \\
11 \mathrm{q} 24.2 \mathrm{q} 24.3 \\
(124784790- \\
129524790)\end{array}$ & $\begin{array}{l}5.4 \mathrm{MB} \\
11 \mathrm{q} 24.2 \mathrm{q} 25 \\
(127128730- \\
132555165)\end{array}$ & \\
\hline \multicolumn{2}{|c|}{ Age at diagnosis (M: months, Y:years) } & $5 \mathrm{M}$ & $33 \mathrm{Y}$ & $65 \mathrm{Y}$ & $6 \mathrm{M}$ & $36 \mathrm{Y}$ & $19 \mathrm{M}$ & $4 \mathrm{Y}$ & $67 Y-P=$ & $8 \mathrm{M}$ & $21 \mathrm{Y}$ & \\
\hline \multicolumn{2}{|c|}{ Intrauterine growth restriction } & - & - & - & + & - & + & - & - & NR & - & NR \\
\hline \multirow[t]{4}{*}{$\begin{array}{l}\text { Neurological } \\
\text { features }\end{array}$} & $\begin{array}{l}\text { Developmental } \\
\text { delay/ID }\end{array}$ & - & - & - & - & - & + & + & $\begin{array}{l}\text { - (but school } \\
\text { difficulties) }\end{array}$ & + & $+(\mathrm{IQ} 50)$ & 85 \\
\hline & $\begin{array}{l}\text { Other } \\
\text { neurological } \\
\text { features }\end{array}$ & - & - & - & $\begin{array}{l}\text { Mild axial } \\
\text { hypotonia }\end{array}$ & - & $\begin{array}{l}\text { Global } \\
\text { hypotonia }\end{array}$ & - & Seizures & & - & \\
\hline & $\begin{array}{l}\text { Abnormal brain } \\
\text { MRI }\end{array}$ & ND & ND & ND & ND & ND & - & & $\begin{array}{l}\text { Periventricular } \\
\text { nodular } \\
\text { heterotopia }\end{array}$ & $\begin{array}{l}\text { Delayed } \\
\text { myelination }\end{array}$ & NR & 51 \\
\hline & $\begin{array}{l}\text { Austim } \\
\text { spectrum } \\
\text { disorders (ASD) }\end{array}$ & - & - & - & - & - & - & + & - & & + & $\begin{array}{l}47 \\
\text { (Akshoomoff,et al. } \\
\text { 2015) }\end{array}$ \\
\hline \multirow[t]{5}{*}{$\begin{array}{l}\text { Hematological } \\
\text { abnormalities }\end{array}$} & $\begin{array}{l}\text { Thrombocytope } \\
\text { nia (PTS) }\end{array}$ & + & + & + & + & + & + & + & - & - & - & 94 \\
\hline & $\begin{array}{l}\text { Transient } \\
\text { anemia }\end{array}$ & + & ND & ND & + & NR & + & + & NR & - & - & NR \\
\hline & $\begin{array}{l}\text { Recurrent } \\
\text { infections }\end{array}$ & - & - & + & - & - & 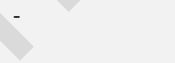 & - & - & NR & - & 54 \\
\hline & Lymphopenia & $\begin{array}{l}+(T, B \text { and NK- } \\
\text { cells) }\end{array}$ & ND & + & $+(T, B, N K)$ & + & NR & NR & - & NR & - & NR \\
\hline & $\begin{array}{l}\text { Quantitative } \\
\text { immunoglobulins }\end{array}$ & Normal & ND & Normal & IgG deficiency & $\begin{array}{l}\text { Global } \\
\text { gammaglobulin } \\
\text { deficiency } \\
(\operatorname{Ig~G,A,~M)~}\end{array}$ & NR & NR & - & NR & - & NR \\
\hline \multirow[t]{3}{*}{ Malformations } & Cardiac & + VSD & + VSD & - & - & - & + & + VSD & - & - & - & 56 \\
\hline & Kidneys & - & NR & NR & $\begin{array}{l}\text { Mild } \\
\text { pyelectasy }\end{array}$ & NR & $\begin{array}{l}\text { Right stenotic } \\
\text { megaurether }\end{array}$ & - & - & & - & 8 \\
\hline & Limb anomalies & $\begin{array}{l}\text { Unilateral } \\
\text { severe foot } \\
\text { brachydactyly }\end{array}$ & - & & $\begin{array}{l}\text { Unilateral } \\
\text { severe hand } \\
\text { brachydactyly } \\
\text {,fifth finger } \\
\text { clinodactyly }\end{array}$ & - & - & - & $\begin{array}{l}\text { Unilateral } \\
\text { transverse limb } \\
\text { defect below } \\
\text { the elbow }\end{array}$ & $\begin{array}{l}5^{\text {th }} \quad \text { finger } \\
\text { shortening, } \\
\text { squaring of the } \\
\text { fingertips }\end{array}$ & - & 87 \\
\hline \multirow[t]{2}{*}{ Sensory defects } & Hearing loss & Mild & - & - & - & - & - & - & - & + & - & NR \\
\hline & $\begin{array}{l}\text { Ophtalmic } \\
\text { anomalies }\end{array}$ & $\begin{array}{l}\text { Strabismus } \\
\text { ptosis } \\
\text { epicanthal } \\
\text { folds }\end{array}$ & $\begin{array}{l}\text { Strabismus, } \\
\text { ptosis }\end{array}$ & - & - & - & $\begin{array}{l}\text { Limitation in } \\
\text { abduction of } \\
\text { right eye } \\
\text { smaller right } \\
\text { eyelid } \\
\text { telecanthus }\end{array}$ & - & Bilateral ptosis & - & - & NR \\
\hline
\end{tabular}




\begin{tabular}{|c|c|c|c|c|c|c|c|c|c|c|c|c|}
\hline \multicolumn{2}{|c|}{ Facial dysmorphic features } & \multirow{2}{*}{-} & \multirow[t]{2}{*}{+} & \multirow[t]{2}{*}{$\begin{array}{l}+ \\
-\end{array}$} & \multirow{2}{*}{ Plagiocephaly } & \multirow[t]{2}{*}{+} & \multirow[t]{2}{*}{+} & \multirow{2}{*}{+} & \multirow[t]{2}{*}{$\begin{array}{l}+ \\
-\end{array}$} & \multirow{2}{*}{$\begin{array}{l}+ \\
\text { Macrocephaly }\end{array}$} & \multirow[t]{2}{*}{$\begin{array}{l}+ \\
\text { Macrocephaly }\end{array}$} & \multirow[t]{2}{*}{$\begin{array}{l}\text { Features } \\
\text { frequency in JS } \\
\text { (\%) (Grossfeld } \\
\text { et al. 2004) } \\
\text { NR }\end{array}$} \\
\hline Head & Skull deformities & & & & & & & & & & & \\
\hline & High forehead & + & + & + & + & + & - & + & & + & + & 31 \\
\hline \multirow[t]{6}{*}{ Eyes } & Sparse eyebrows & + & - & - & + & - & - & + & & - & - & 65 \\
\hline & Hypertelorism & + & + & + & + & - & - & + & & - & - & 97 \\
\hline & $\begin{array}{l}\text { Downslanting } \\
\text { palpebral fissures }\end{array}$ & + & + & + & + & + & - & - & + & - & - & 91 \\
\hline & Strabismus & + & + & - & - & - & - & - & - & - & - & 74 \\
\hline & Ptosis & + & + & - & - & - & - & - & + & - & - & 68 \\
\hline & Epicanthal folds & + & - & - & - & - & + & - & - & - & - & 44 \\
\hline \multirow[t]{4}{*}{ Nose } & Broad nasal bridge & + & - & + & + & - & - & - & - & + & + & 86 \\
\hline & Flat nasal bridge & + & + & + & + & - & - & - & - & + & + & 46 \\
\hline & Short nose & + & + & + & + & + & - & + & - & + & + & 75 \\
\hline & $\begin{array}{l}\text { Anteverted } \\
\text { nostrils }\end{array}$ & + & + & - & + & - & - & + & - & - & - & 71 \\
\hline \multirow[t]{2}{*}{ Ears } & Low-set ears & + & + & - & + & - & - & - & + & - & + & 83 \\
\hline & Dysplastic ears & + & + & + & + & + & + & - & - & + & - & 91 \\
\hline \multirow[t]{3}{*}{ Mouth } & Long philtrum & + & + & + & + & + & - & - & - & - & - & 63 \\
\hline & Thin upper lip & + & + & + & + & + & - & + & + & - & - & 91 \\
\hline & $\begin{array}{l}\text { Downturned } \\
\text { corners of the } \\
\text { mouth }\end{array}$ & + & + & + & + & + & - & - & - & - & - & 77 \\
\hline Neck & Short neck & + & + & + & + & + & - & + & - & - & + & 64 \\
\hline
\end{tabular}

Table 1. Comparative clinical and molecular features between Family A and B patients, and previously reported cases with interstitial or short terminal deletions encompassing 11q24.2q24.3 region

ND: not done, NR: not reported, ID: Intellectual disability, MRI: magnetic resonance imaging, PTS: Paris-Trousseau Syndrome, VSD: ventricular septal defect 